\title{
Jerzy Dębski, Oficerowie Wojska Polskiego w obozie koncentracyjnym Auschwitz 1940-1945. Slownik biograficzny, \\ t. 1-6, t. 1: ss. 412, t. 2: ss. 340; t. 3: ss. 384; t. 4: ss. 319, t. 5: ss. 303; t. 6: ss. 326, Oświęcim 2016, Państwowe Muzeum Auschwitz-Birkenau
}

W warsztacie badawczym historyka dziejów najnowszych wszelkie słowniki biograficzne zawsze odgrywały ważną rolę. Trudno nie docenić ich znaczenia z powodu mnogości merytorycznych informacji, nie można też pominąć wartości wskazówek źródłoznawczych. Obok wielotomowych długoletnich edycji, takich jak Polski słownik biograficzny, niezmiernie cenne są słowniki biograficzne poświęcone wyodrębnionej i określonej grupie społecznej. Mogą one zawierać albo ustaloną i w pełni znaną liczbę nazwisk, albo mieć charakter otwarty, czyli pomimo zamknięcia redakcyjnego tomów, brakuje całkowitej pewności, czy zakres postaci prezentowany w publikacji jest zbiorem skończonym. Recenzowana tu pozycja dotyczy przypadku drugiego. Poświęcona została jednostkowym losom oficerów Wojska Polskiego, którzy znaleźli się w obozie koncentracyjnym Auschwitz.

Omawiany słownik biograficzny autorstwa pracownika Państwowego Muzeum Auschwitz-Birkenau w Oświęcimiu Jerzego Dębskiego nosi tytuł Oficerowie Wojska Polskiego w obozie koncentracyjnym Auschwitz 1940-1945. Stownik biograficzny. Jest próbą wyjścia naprzeciw postulatom badawczym w zakresie badań nad polskim korpusem oficerskim doby II Rzeczypospolitej i czasu wojny. Publikacja nie jest przedsięwzięciem przypadkowym, ale projektem dokładnie przemyślanym i opracowywanym przez wiele lat. Nie budzi to zdziwienia, autor bowiem jest doświadczonym historykiem i muzealnikiem. J. Dębski urodził się w 1949 r. Studiował historię na Uniwersytecie Jagiellońskim, natomiast pracę doktorską Kadra dowódcza SZP-ZWZ-AK w Konzentrationslager Auschwitz-Birkenau 1940 1945 obronił w 2006 r. na Uniwersytecie Pedagogicznym również w Krakowie. Jest pracownikiem Państwowego Muzeum Auschwitz-Birkenau w Oświęcimiu od 1978 r., aktualnie w stopniu kustosza. Jego zaintereso- 
wania badawcze ogniskują się wokół aktywności Polskiego Państwa Podziemnego wobec KL Auschwitz, jak również kwestii Romów w KL Auschwitz. Z prac naukowych należy wymienić: Księgi zgonów z Auschwitz. Fragmenty, wydane pod jego redakcją (München 1995), Okrutna przestroga - opracowanie wspólne z Leonem Popkiem (Lublin 1997), Prześladowania i masowa zagłada Romów podczas II wojny światowej w świetle relacji $i$ wspomnień, pod redakcją i opracowaniem J. Dębskiego i Joanny Talewicz-Kwiatkowskiej (Warszawa 2007) oraz dzieło stanowiące swoiste preludium do słownika będącego przedmiotem niniejszej recenzji: Kadra dowódcza SZP-ZWZ-AK w Konzentrationslager Auschwitz 1940-1945 (Katowice-Oświęcim 2009).

Losy i biografie oficerów okresu II Rzeczypospolitej cieszą się dużą popularnością wśród badaczy dziejów najnowszych Polski, nie tylko o zacięciu biografistycznym ${ }^{1}$. Warto zwrócić uwagę, że historycy zajmujący się

${ }^{1}$ Tczewski panteon katyński. Jeżeli zapomnę o Nich, Ty, Boże na niebie, zapomnij o mnie, Marcin Kłodziński, Tczew 2017; Robert Adamek, Ofiary zbrodni katyńskiej z Pabianic. 1940 rok, Pabianice 2016; Piotr Kozłowski, Zapomniani obrońcy granic południowo-wschodnich II Rzeczypospolitej 1922-1939. Słownik biograficzny oficerów, strażników oraz pracowników kontraktowych straży celnej i straży granicznej, Przemyśl 2015; Mieszkańcy Gostynia i okolic w mogiłach katyńskich, oprac. Wojciech Śmigielski, Gostyń 2015; Nasi ojcowie. Ofiary zbrodni katyńskiej, których rodziny zamieszkuja Podbeskidzie, red. Marzenna Burczak, Anna Farny, Zofia Lamers, Jerzy Pisowicz, Bielsko-Biała 2015; Katyń, Charków, Twer. Chetmskie ofiary zbrodni sowieckich, oprac. Janusz Paweł Krzywicki i Zbigniew Sławomir Lubaszewski, Chełm 2013; Czesław Sterkowicz, Ofiary Golgoty Wschodu zamordowani Synowie ziemi tarnowskiej, bocheńskiej, brzeskiej, dąbrowskiej i dębickiej, Tarnów 2013; Tadeusz Zych, Tarnobrzescy katyńczycy, Stalowa Wola 2013; Dionizy Garbacz, Niżańsko-stalowowolska lista katyńska, Stalowa Wola 2011; Sebastian Tuliński, Synowie Grodziska Wielkopolskiego, Granowa, Kamieńca, Rakoniewic, Wielichowa w dołach śmierci Katynia, Charkowa, Miednoje, Grodzisk Wielkopolski 2011; Jan Bajor, Niezłomni. Zapomniani bohaterowie Siedlec, Siedlce 2010; Janina Pańczakowa, Małgorzata Cichoń, Powstańcy wielkopolscy $w$ grobach katyńskich, Poznań 2010; Alfred Kabata, Pamięć o Katyniu w Nowym Dworze Mazowieckim. Oficerowie Batalionu Elektrotechnicznego zamordowani w Katyniu i Charkowie, Nowy Dwór Mazowiecki 2011; Zbigniew Kiełb, Przerwane życiorysy... listy katyńskie osób zwiazanych z Puławami i powiatem puławskim oraz Dęblinem do roku 1939, Lublin 2010; Zdzisław Kościański, Nowotomyska lista katyńska: historia i pamięć, Nowy Tomyśl 2010; Żotnierze Września polegli i pomordowani na Wschodzie, red. Andrzej Wesołowski przy współudziale Kamila Stepana, Warszawa 2010; Michał Siwiec-Cielebon, Vinctis non victis: pokonanym nie zwyciężonym: Wadowicka Lista Katyńska: synowie Ziemi Wadowickiej i żołnierze garnizonu 
grupą zawodową, za jaką można uznać korpus oficerski Wojska Polskiego, wykorzystują różne narzędzia metodologiczne. Obok klasycznego rekonstruowania historii stosowane są badania prozoprograficzne czy kwantytatywne. Często tematem zajmują się regionaliści, którzy starają się opisywać jednostkowe losy oficerów, posługując się kluczem terytorialnym, osadzając przedstawicieli tej grupy zawodowej na tle lokalnych społeczności.

Obecny powszechnie w okresie międzywojennym etos walk o niepodległość, jak również stworzone przez ówczesny aparat władzy mity związane z jej odzyskaniem czyniły z tej grupy wyjątkowy element na mapie społeczeństwa II Rzeczypospolitej, grupy przypomnijmy niejednorodnej, w skład której wchodzili oficerowie służący przed I wojną światową i w jej trakcie w rozmaitych formacjach zbrojnych wielu państw. Oczywiście w sporej części byli to Legioniści, jak i żołnierze innych formacji o polskim charakterze, walczący na wszystkich frontach Wielkiej Wojny, oficerowie państw

Wadowice polegli i pomordowani w wyniku agresji sowieckiej 1939-1940 r., Wadowice 2010; Piotr Szopa, Zbrodnia katyńska 1940: pamięci mieszkańców powiatu strzyżowskiego zamordowanych przez Sowietów w Katyniu, Charkowie i Twerze (Kalininie), Rzeszów [2010?]; Zbrodnia katyńska. Wielkopolanie w dołach śmierci Katynia, Charkowa i Miednoje, wystawa IPN, Poznań 2010; W 70. rocznicę zbrodni katyńskiej (1940-2010), wieliczanie, jeńcy wojenni Kozielska - Ostaszkowa - Starobielska zamordowani w ZSRR w 1940 r., oprac. Jadwiga Duda, Wieliczka 2010; Artur Ochał, Stownik oficerów i chorążych Korpusu Ochrony Pogranicza w Suwałkach (1929-1939), Suwałki 2009; Wiktor Krzysztof Cygan Oficerowie Legionów Polskich 1914-1917. Słownik biograficzny, t. 1, Warszawa 2005, t. 2, Warszawa 2006, t. 4, Warszawa 2006; Lech Mastalski, Oficerowie czestochowskiej 7 Dywizji Piechoty zamordowani na Wschodzie w 1940 roku: noty biograficzne, Kraków 2005; Stanisław Zając, Ocalić od zapomnienia. Pracownicy naukowi oraz absolwenci - wychowankowie Uniwersytetu Jagiellońskiego - oficerowie Wojska Polskiego ofiary zbrodni stalinowskiego NKWD - 1940 r., Kraków 2002; Kazimierz Banaszek, Wanda Krystyna Roman, Zdzisław Sawicki, Kawalerowie Orderu Virtuti Militari w mogiłach katyńskich, Warszawa 2000; Andrzej Rybicki, Jan Brzeski, Andrzej Kostrzewski, Uniwersytecka księga katyńska. Pamięci pracowników naukowych Uniwersytetu Jagiellońskiego zamordowanych wiosna 1940 roku przez NKWD, Kraków 2000; Piotr Stawecki, Oficerowie dyplomowani Wojska Drugiej Rzeczypospolitej, Warszawa 1997; Pi otr Staw ecki, Słownik biograficzny generałów Wojska Polskiego, Warszawa 1994; Jerzy Giza, Nowosądecka lista katyńska: Sadeczanie i oficerowie 1 pułku strzelców podhalańskich, jeńcy obozów w Kozielsku, Ostaszkowie i Starobielsku pomordowani w Rosji Sowieckiej, Kraków 1991; Tadeusz Kryska-Karski, Stanisław Żurakowski, Generałowie Polski niepodległej, Warszawa 1991; Wiktor Krzysztof Cygan, Słownik biograficzny oficerów Legionów Polskich, t. 1, Warszawa 1992, t. 2, Warszawa 1998. 
zaborczych, ale także służący w wojskach państw Ententy. W grupie tej, jakkolwiek niejednolitej, podzielonej rozmaitymi tradycjami, zwyczajami, czy nawet antagonizmami, a przede wszystkim pojmowaniem rzeczywistości w nowej odsłonie, z czasem prym zaczęli wieść oficerowie wywodzący się z Legionów Polskich, uczestnicy walk o niepodległość i granice z lat 1914-1921. Dość szybko podjęli działania poza ramami wojska, weszli do szeregów administracji, polityki w różnych odmianach i rozdaniach, mając realny wpływ na ówczesne wydarzenia. Grupa ta zdominowała wkrótce, a z czasem zmonopolizowała, życie społeczno-polityczne Polski międzywojennej. Do grupy oficerów II Rzeczypospolitej stopniowo zaczęło dołączać pokolenie urodzone tuż przed Wielką Wojną, więc niepamiętające okresu zaborów. Wyrosłe w kulcie walk o niepodległość w latach 1914-1921, rozpoczęło służbę oficerską tuż przed wybuchem nowej wojny. To właśnie młodsi oficerowie, niemający doświadczeń walk I wojny światowej, byli później tą grupą w konspiracji, która chciała nadawać ton walce podziemnej, pozostając obok pokolenia „Kolumbów” - swoich podwładnych, najbardziej radykalną częścią sił zbrojnych w konspiracji. Taka postawa skutkowała zapewne dużymi stratami osobowymi, jakie to pokolenie młodszych oficerów poniosło podczas działalności konspiracyjnej.

Pomimo popularności biograficznych badań dotyczących oficerów Wojska Polskiego można dostrzec dysproporcje w podejmowanych tematach. Na przykład badacze ze szczególnym zaangażowaniem podeszli do wypełniania „białej plamy” - czyli zbrodni katyńskiej. Wielu historyków podejmowało biograficzne badania dotyczące grupy oficerów zamordowanych przez NKWD w 1940 r., grupy o tyle ciekawej, że dużą jej część stanowili oficerowie rezerwy reprezentujący w cywilu warstwę inteligencką. To również stanowi o wyjątkowości tej części korpusu oficerskiego.

Kolejną, chociaż nie tak eksponowaną w dotychczasowych badaniach, jest grupa oficerów z okresu II Rzeczypospolitej, która trafiła do niewoli niemieckiej. Tutaj dorobek badawczy jest również spory, głównie za przyczyną, ale nie tylko, Centralnego Muzeum Jeńców Wojennych w Łambinowicach-Opolu, które takie badania z sukcesem prowadzi od wielu lat. Nadal jednak nie powstał ani jeden słownik biograficzny oficerów, którego kryterium doboru postaci byłoby osadzenie w obozie jenieckim. Brakuje także wydawnictwa opisującego jednostkowe losy oficerów internowanych w Rumunii i na Węgrzech. Tym bardziej należy zwrócić uwagę na recenzowaną pozycję. 
Hasła w sześciu tomach ułożone są w systemie holenderskim, a więc w każdym w ułożeniu alfabetycznym od A do Ż. Łącznie opracowano 1515 biogramów. Ich objętość jest zróżnicowana, uzależniona od skali i jakości zdobytych podczas kwerendy materiałów. Pierwszy tom otwiera obszerny wstęp odautorski. J. Dębski przedstawia w nim przedmiot swoich zainteresowań, opisując jedną z najważniejszych grup społecznych w II Rzeczypospolitej - korpus oficerski. Obok każdego biogramu znajduje się podana mniejszą czcionką obszerna bibliografia, na którą składa się wykorzystana literatura oraz źródła. Autor wyczerpująco wykorzystał dotychczasowy dorobek naukowo-badawczy macierzystego muzeum, zwłaszcza dla szczegółowego przedstawienia obozowych epizodów życia każdego z 1515 bohaterów biogramów. Struktura biogramów jest ujednolicona. Przedstawia podstawowe dane, takie jak dzienne daty i miejsca urodzin oraz śmierci - ten ostatni fakt, o ile zaszedł w obozie koncentracyjnym, opatrzony jest możliwie najbardziej szczegółowym opisem zgonu. Zawarta jest również charakterystyka rodziny, jak też droga edukacji, ścieżka zawodowa, w której szczególnie skupiono się na służbie w różnych formacjach I wojny światowej, a później w Wojsku Polskim. Autor nie ominął konspiracyjnych wątków w życiorysach, tam gdzie się pojawiły. Zaangażowanie w konspirację było częstą bezpośrednią przyczyną osadzenia w obozie. Przede wszystkim jednak autor starał się o możliwie pełne przedstawienie, zgodnie z zakresem tematycznym słownika, obozowych losów prezentowanych osób. Teksty zamykają opisy dotyczące lat powojennych, o ile bohaterowi biogramu udało się przeżyć pobyt w obozie. Zwieńczeniem są informacje o działalności społecznej, otrzymanych odznaczeniach oraz o sytuacji rodzinnej. Widać, że autor starał się, aby biogramy nie były jedynie zbiorem suchych faktów ułożonych chronologicznie i związanych z bohaterem danego tekstu. Tam gdzie się dało, rozwijał nieco szerszą narrację historyczną, która pozwala na precyzyjniejsze określenie znaczenia i roli w procesie historycznym danej postaci. Porównując biogramy, można stwierdzić, że charakter żadnego z nich nie jest identyczny - mimo że wszystkie wyszły spod pióra jednego historyka - nie nastąpiło ,zglajszachtowanie” życiorysów, każdy z osobna oddaje charakter postaci oraz jest odbiciem zgromadzonej podstawy bibliograficznej.

Z pewnością nigdy nie poznamy pełnej listy nazwisk oficerów Wojska Polskiego, którzy znaleźli się w KL Auschwitz. Ten stan rzeczy wynika z kilku ważkich czynników bezpośrednio związanych ze strukturą zasobu 
bazy źródłowej, z którą pracował autor słownika. Stan zachowania dokumentów wytworzonych w obozie, a odnoszących się do więźniów narodowości polskiej, pozostaje w daleko idącej dysproporcji w stosunku do ilości tych związanych z więźniami obozu narodowości żydowskiej. Niemcy zniszczyli dużą część materiału aktowego dotyczącego polskich więźniów. Już z tego choćby względu nie można liczyć na ustalenie pełnej listy. Dodatkowym utrudnieniem są dane zawarte w aktach personalnych, na podstawie których administracja obozowa identyfikowała osobę więźnia. Oficerowie nierzadko posługiwali się fałszywymi danymi wpisywanymi do posiadanych dokumentów i takie informacje wykorzystywali Niemcy, o ile nie udało im się odkryć prawdziwej tożsamości więźnia. Identyfikacja wszystkich oficerów Wojska Polskiego, z przyczyn obiektywnych, na pewno nie może się więc zakończyć pełnym sukcesem.

Oprócz akt administracji obozowej autor opierał się również na materiałach będących wynikiem prowadzonego przez pracowników muzeum procesu gromadzenia źródeł w ramach kontaktów z byłymi więźniami obozu w postaci korespondencji czy ankiet. Spośród dokumentów obozowych wykorzystano przede wszystkim wszelkie źródła o charakterze ewidencyjnym, takie jak: listy osób nowo przybyłych do KL Auschwitz w kolejnych transportach, spisy ewidencyjne więźniów zarejestrowanych w poszczególnych blokach i wykazy zatrudnianych, dokumenty medyczne wytwarzane przez komórki podległe naczelnemu lekarzowi garnizonu SS. Sięgnięto także do dokumentów budzącego grozę wśród więźniów Wydziału II Politycznego, w którym służyli funkcjonariusze katowickiego Gestapo lub Kripo. Do ustalenia dalszych losów więźniów posłużyły listy transportowe do innych obozów, a wobec tych, którzy stracili życie w obozie, pomocne były różnego rodzaju wykazy dotyczące zgonów. Niepełny stan zachowania poszczególnych rodzajów źródeł wytworzonych przez administrację obozową i wynikające $\mathrm{z}$ niego duże luki czasowe $\mathrm{w}$ aktach zmusiły autora do uzupełnienia bazy źródłowej o inne zbiory archiwalne. Przetrwałe dokumenty obozowe nie dają oczywiście, wobec tego co napisano powyżej, pełnego obrazu biogramu więźnia, a jedynie informują o podstawowych faktach dotyczących życia obozowego.

Autor słownika sięgnął także do sfery źródłowej zwykle wykorzystywanej przez historyków wojskowości II Rzeczypospolitej - materiałów archiwalnych Centralnego Archiwum Wojskowego, przede wszystkim teczek personalnych oficerów. Korzystał ponadto z oficjalnych wydawnictw 
Ministerstwa Spraw Wojskowych z okresu międzywojennego: roczników oficerskich czy dzienników personalnych. Na uznanie zasługuje pozyskanie materiałów z prywatnych zbiorów rodzin oficerów. Luki w materiałach źródłowych i niejasności autor próbował wyjaśniać, prowadząc korespondencję z różnymi instytucjami mogącymi dysponować potrzebnymi informacjami. Niektóre z biogramów oparte są ponadto na źródłach historycznych wykorzystywanych standardowo w badaniach genealogicznych jak księgi metrykalne. Tam, gdzie było to niezbędne, autor sięgnął po dokumenty charakterystyczne dla pracy naukowej historyka dziejów nauki, czyli np. akta archiwów uniwersyteckich w postaci wszelkich ewidencji, jak albumy studentów czy teczki personalne kadry uczelnianej.

J. Dębski korzystał także z licznych tzw. Ksiag pamięci - redagowanych zestawień osób deportowanych do obozu z określonego terytorium. Autor sięgał ponadto do współczesnej prasy codziennej, w której zamieszczano liczne przyczynki poświęcone opisywanym w słowniku postaciom. Tam gdzie uznał to za pożądane, wspomagał się ogólną literaturą przedmiotu, obejmującą podstawowe pozycje opisujące okupację dokonaną przez III Rzeszę.

Zainteresowany konkretnymi postaciami historyk powinien zadać sobie pytanie, na ile zredagowany biogram wyczerpuje opis życia oficera. Czy możliwe jest odnalezienie jeszcze dodatkowych informacji, które będą istotne dla oglądu prezentowanych postaci w tym słowniku? Odpowiedź na pewno będzie twierdząca, co nie deprecjonuje ogromnego wysiłku i zaangażowania autora włożonych w redagowanie kilkunastu setek biogramów. Jak wcześniej wspomniano, słownik ma za zadanie uwypuklać „moment obozowy" w życiorysie, przy okazji przedstawiając jednak szereg nie mniej interesujących, ważnych i potrzebnych historykowi faktów. Dostaje on również, niejako „na talerzu” dobrze opracowane bibliografie, które mogą stać się punktem wyjścia do dalszych badań.

Każdy tom zaopatrzony jest w indeks osobowy ułatwiający korzystanie z publikacji, jak również wykaz stosowanych skrótów. Docenić także należy bardzo dobry poziom edytorski i estetyczny słownika - tomy w poręcznym formacie, w twardych okładkach, przy klarownym, miłym dla oka łamaniu tekstu w postaci dwóch kolumn, z których lewa to biogram, a prawa, z zastosowaną mniejszą czcionką, to bibliografia. Warto podkreślić, że to sześciotomowe dzieło jest pracą tylko jednego autora. Zazwyczaj zgromadzenie tak dużego ładunku poznawczego jest dziełem kilku lub kilkunastu osób. Tym 
bardziej więc zwracają uwagę wielotomowe słowniki biograficzne opracowane przez jednego autora. Recenzowana publikacja to klasyczny „koń roboczy" dla historyków wojskowości, konspiracji, dziejów politycznych i społecznych, jak również badaczy regionalnych. Będą po to wyjątkowe dzieło J. Dębskiego często i chętnie sięgać. Należy więc raz jeszcze złożyć szczególne wyrazy uznania i pochwały zarówno dla samego autora, jak i jego macierzystej instytucji, która wydała publikację. Wypada pokusić się na koniec o słowa zachęty dla innych historyków, którzy powinni zdecydować się na opracowywanie takich cennych i wartościowych pozycji. Historiografia polska na pewno wiele na tym zyska.

Liliana Kaczor Archiwum Uniwersytetu Pedagogicznego im. Komisji Edukacji Narodowej w Krakowie 